\title{
Uji Daya Hasil Lanjutan 30 Galur Padi Tipe Baru Generasi F6 Hasil dari 7 Kombinasi Persilangan
}

\author{
Advanced Yield Trials of 30 F6 Line New Plant Type with 7 Crosses Combination
}

\author{
Rafiatul Rahmah, Hajrial Aswidinnoor*
}

Departemen Agronomi dan Hortikultura, Fakultas Pertanian, Institut Pertanian Bogor (Bogor Agricultural University), Jl. Meranti, Kampus IPB Dramaga, Bogor 16680, Indonesia

Telp. \& Faks.62-251-8629353 e-mail agronipb@indo.net.id

*Penulis untuk korespondensi: hajrial@ipb.ac.id

Disetujui 24 Desember 2013/Published Online 10 Januari 2014

\begin{abstract}
Rice is an important crop in Indonesia. Advanced yield trial is one procedur in the process of producing new varieties. This experiment used Randomized Complete Block Design. Plant materials were 30 F6 lines of new type and four check varieties i.e Ciherang, Inpari 13, IPB 4S, and IR 64. The result showed that plant height ranged from 95-126.5 cm, number of grain per penicle from 114-251, percentage of filled grain from 57-91\% and weight of 1000 grains ranging from 24.541-31.047 gram. The yield of IPB159-F-1, IPB159-F-13 and IPB160-F-1 line were 8.1 ton ha ${ }^{-1}, 7.9$ ton $\mathrm{ha}^{-1}$ and 7.8 ton ha $\mathrm{a}^{-1}$, respectively.
\end{abstract}

Keywords: IPB rice lines, Oryza sativa, IPB $4 S$

ABSTRAK

Padi merupakan tanaman penting di Indonesia. Salah satu proses untuk menghasilkan padi varietas baru adalah dengan menguji saya hasil lanjutan. Penelitian ini menggunakan Rancangan Kelompok Lengkap Teracak (RKLT). bahan yang digunakan adalah 30 galur padi tipe baru serta empat varietas pembanding yaitu Ciherang, Inpari 13, IPB 4S dan IR 64. Hasil menunjukkan bahwa tinggi tanaman berkisar 95-126.5 cm, jumlah gabah total per malai berkisar 114-251, persentase gabah isi berkisar 57-91\% dan bobot 1000 butir berkisar 24.541-31.047 gram. Galur IPB159-F-1, IPB159-F-13 dan IPB160-F-1 memiliki potensi hasil masing-masing 8.1 ton ha-1, 7.9 ton ha-1 dan 7.8 ton ha $^{-1}$.

Kata kunci: galur padi IPB, Oryza sativa, IPB $4 S$

\section{PENDAHULUAN}

Komoditas pangan terbesar di Indonesia adalah padi (Oryza sativa), karena merupakan sumber makanan pokok bagi sebagian besar penduduk Indonesia. Permintaan akan beras semakin meningkat seiring dengan bertambahnya populasi penduduk. Kemajuan di bidang pertanian sangat dibutuhkan dalam usaha memenuhi kebutuhan pangan yang tinggi, khususnya di Indonesia.

Menurut data Badan Pusat Statistik (BPS) 2011, produksi padi pada tahun 2011 diperkirakan sebesar 65390000 ton gabah kering giling (GKG), mengalami penurunan sebanyak 1080 000 ton (1.63\%) dibandingkan tahun 2010. Penurunan produksi diperkirakan terjadi karena penurunan luas panen yaitu seluas 29700 hektar
$(0.22 \%)$ dan produktivitas sebesar 0.71 kuintal ha${ }^{1}(1.42 \%)$. Produksi padi pada tahun 2012 sebesar 69060000 ton GKG atau mengalami kenaikan sebesar 3300000 ton (5.02\%) dibandingkan tahun 2011 (BPS, 2012). Kenaikan produksi terutama dapat dicapai melalui tersedianya varietas unggul baru (Makarim dan Suhartatik, 2006).

Sejak tahun 1950-an, hasil padi negara berkembang di Asia bertahan pada tingkat produktivitas sangat rendah $\left(<1.5\right.$ ton $\left.\mathrm{ha}^{-1}\right)$. Negara-negara tersebut mengandalkan kenaikan produksi padi kepada perluasan area tanam atau ekstensifikasi. Laju pertumbuhan penduduk sebesar $1.49 \%$ selama 10 dekade terakhir mengharuskan produktivitas padi yang tinggi hingga $>6$ ton ha-1 (BPS, 2012). Las et al. (2003) menyatakan bahwa potensi hasil PTB 10-25\% 
tebih tinggi dibandingkan dengan varietas unggul yang ada saat ini.

Memajukan pertanian terutama untuk memenuhi kebutuhan memiliki kendala fisik maupun sosial ekonomi yang menghambat perluasan areal pertanaman padi, sehingga kebutuhan beras di Indonesia belum dapat dipenuhi. Hal ini mengakibatkan titik tumpu peningkatan produksi padi nasional terletak pada usahapeningkatan produktivitas, salah satunya melalui pembentukan varietas unggul berdaya hasil tinggi (Las, et al., 2004).

Upaya pembentukan varietas unggul berdaya hasil tinggi membutuhkan beberapa tahap salah satunya pengujian daya hasil. Tahap ini dibutuhkan untuk menguji daya hasil galur-galur padi yang telah ada, kemudian diseleksi untuk dikembangkan menjadi varietas.

Tujuan penelitian ini adalah untuk menguji daya hasil 30 galur padi tipe baru generasi F6 dari hasil 7 kombinasi persilangan dan 4 varietas pembanding di Desa sindang
Barang Kecamatan Laladon, Bogor, Jawa Barat. Galur yang berdaya hasil baik akan diseleksi untuk pembentukan varietas unggul yang memberikan manfaat terhadap peningkatan produktivitas dan produksi padi.

\section{BAHAN DAN METODE}

Penelitian ini dilaksanakan pada bulan MeiSeptember 2012 di Sindang Barang, Kabupaten Bogor, Provinsi Jawa Barat.

Bahantanam yang digunakan adalah 30 galur padi hasil seleksi yang berasal dari persilangan IPB117-F-5-1-1 x IR64 (3 galur), IPB98-F-5-1-1 x IR64 (13 galur), Cimelati $x$ IPB97-F-31-1-1 (2 galur), IPB117-F-5-1-1 $\mathrm{x}$ INPARI 1 (3 galur), IR64 x IPB117-F-19-1-1 (3 galur), IPB113-F-2-1-1 x IR64 (3 galur), IR64 x IPB117-F-61-1-1 (3 galur), dan 4 varietas pembanding yaitu varietas Ciherang, INPARI 13, IPB4S dan IR 64 (Tabel 1).

Tabel 1. Galur Padi Tipe Baru (PTB) hasil seleksi dari 7 persilangan dan 4 varietas pembanding

\begin{tabular}{clllll}
\hline No & Galur/varietas & Tetua Persilangan & No & Galur/varietas & Tetua Persilangan \\
\hline 1 & IPB158-F-1 & IPB117-F-5-1-1 x IR64 & 18 & IPB160-F-2 & Cimelati x IPB97-F-31-1-1 \\
2 & IPB158-F-2 & IPB117-F-5-1-1 x IR64 & 19 & IPB163-F-1 & IPB117-F-5-1-1 x INPARI 1 \\
3 & IPB158-F-3 & IPB117-F-5-1-1 x IR64 & 20 & IPB163-F-2 & IPB117-F-5-1-1 x INPARI 1 \\
4 & IPB159-F-1 & IPB98-F-5-1-1 x IR64 & 21 & IPB163-F-3 & IPB117-F-5-1-1 x INPARI 1 \\
5 & IPB159-F-2 & IPB98-F-5-1-1 x IR64 & 22 & IPB165-F-1 & IR64 x IPB117-F-19-1-1 \\
6 & IPB159-F-3 & IPB98-F-5-1-1 x IR64 & 23 & IPB165-F-2 & IR64 x IPB117-F-19-1-1 \\
7 & IPB159-F-4 & IPB98-F-5-1-1 x IR64 & 24 & IPB165-F-3 & IR64 x IPB117-F-19-1-1 \\
8 & IPB159-F-5 & IPB98-F-5-1-1 x IR64 & 25 & IPB167-F-1 & IPB113-F-2-1-1 x IR64 \\
9 & IPB159-F-6 & IPB98-F-5-1-1 x IR64 & 26 & IPB167-F-2 & IPB113-F-2-1-1 x IR64 \\
10 & IPB159-F-7 & IPB98-F-5-1-1 x IR64 & 27 & IPB167-F-3 & IPB113-F-2-1-1 x IR64 \\
11 & IPB159-F-8 & IPB98-F-5-1-1 x IR64 & 28 & IPB168-F-1 & IR64 x IPB117-F-61-1-1 \\
12 & IPB159-F-9 & IPB98-F-5-1-1 x IR64 & 29 & IPB168-F-2 & IR64 x IPB117-F-61-1-1 \\
13 & IPB159-F-10 & IPB98-F-5-1-1 x IR64 & 30 & IPB168-F-3 & IR64 x IPB117-F-61-1-1 \\
\cline { 3 - 5 } 14 & IPB159-F-11 & IPB98-F-5-1-1 x IR64 & 31 & Ciherang & \\
15 & IPB159-F-12 & IPB98-F-5-1-1 x IR64 & 32 & INPARI 13 & \\
16 & IPB159-F-13 & IPB98-F-5-1-1 x IR64 & 33 & IPB 4S & \\
17 & IPB160-F-1 & Cimelati x IPB97-F-31-1-1 & 34 & IR 64 & \\
\hline
\end{tabular}

Penelitian ini menggunakan perlakuan 30 galur PTB dan 4 varietas pembanding yang masing-masing diulang 3 kali sehingga terdapat 102 satuan percoban. Penelitian menggunakan rancangan percobaan Rancangan Kelompok
Lengkap Teracak (RKLT) dan data hasil pengamatan diolah software SAS System dan dilakukan uji lanjut dengan perbandingan ganda DMRT (Duncan Multiple Range Test) apabila 
hasil analisis ragam lebih besar dari 5\% (Gomez dan Gomez, 1995).

Benih disemai pada bedeng persemaian basah, di samping kanan dan kiri bedeng dibuat parit dengan ketinggian di bawah permukaan bedeng. Air melalui parit tersebut untuk mempertahankan bedengan dalam keadaan basah. Benih disemai dengan cara ditabur rata.

Jarak tanam yang digunakan adalah $25 \mathrm{~cm}$ x $25 \mathrm{~cm}$. Jumlah plot percobaan yang dibutuhkan sebanyak 102 satuan percobaan, dengan luas petak 7.5-9 $\mathrm{m}^{2}$. Bibit hasil persemaian dipindah tanam (transplanting) setelah berumur 21 hari dan ditanam 1 bibit/lubang.

Pengamatan yang dilakukan terdiri dari pengamatan petakan dan pengamatan tanaman contoh. Pengamatan petakan terdiri dari pengamatan umur berbunga $80 \%$ sudah bermalai, umur panen dan produksi panen petakan per hektar gabah kering giling (ton ha $\left.\mathrm{A}^{-1}\right)$. Pengamatan tanaman contoh dilakukan dengan mengamati empat tanaman contoh untuk setiap galur per ulangan. Karakter-karakter yang diamati yaitu: tinggi tanaman (diukur dari permukaan tanah sampai daun bendera yang masih tegak), jumlah anakan produktif, panjang daun bendera, umur berbunga (saat $80 \%$ masing-masing galur berbunga), umur panen (dihitung saat 90-95\%) gabah dalam setiap galur telah masak/menguning), panjang malai (diukur dari buku terakhir malai sampai ujung malai), bobot 1000 butir (g), jumlah gabah total/malai, jumlah gabah isi/malai, jumlah gabah hampa/malai, persentase gabah isi, persentase gabah hampa, pengamatan hama dan penyakit tanaman sebagai data tambahan. Tanaman percobaan dipupuk dengan $300 \mathrm{~kg} \mathrm{ha}^{-1}$ Phonska, dan $150 \mathrm{~kg} \mathrm{ha}^{-1}$ Urea. Alat yang digunakan yaitu alat pertanian yang umum digunakan untuk budidaya padi, timbangan analitik, alat ukur KA, dan penggaris.

\section{HASIL DAN PEMBAHASAN}

\section{Karakteristik Galur-galur Padi Tipe Baru}

Nilai koefisien keragaman (KK) menunjukkan tingkat ketepatan dengan perlakuan yang diperbandingkan dan merupakan indeks yang baik dari keadaan percobaan (Gomez dan Gomez, 1995). Nilai KK yang rendah menunjukkan derajat ketelitian yang tinggi. Nilai KK yang terlalu rendah menyebabkan terlalu banyak perlakuan-perlakuan yang menonjol, dan sebaliknya nilai KK terlalu besar akan menyebabkan tidak adanya perlakuan yang menonjol. Nilai koefisien keragaman tertinggi terdapat pada karakter gabah hampa, sedangkan nilai koefisien keragaman terendah terdapat pada karakter umur panen.

Tabel 2. Rekapitulasi sidik ragam

\begin{tabular}{llr}
\hline Karakter & F Hitung & KK $(\%)$ \\
\hline Tinggi tanaman & $4.39 * *$ & 5.26408 \\
Panjang malai & $1.72 *$ & 10.17427 \\
Panjang daun bendera & $2.76^{*}$ & 12.94904 \\
Jumlah anakan produktif & $2.71 *$ & 14.75893 \\
Gabah isi & $4.43 * *$ & 16.27889 \\
Gabah total & $6.02 * *$ & 14.21183 \\
Persentase gabah isi & $2.93 *$ & 12.23029 \\
Persentase gabah hampa & $2.38^{*}$ & 33.11940 \\
Bobot 1000 butir & $2.17 * *$ & 6.94809 \\
Produktivitas (ton ha-1) & $1.77 *$ & 15.13530 \\
Umur berbunga & $5.57 * *$ & 3.62842 \\
Umur panen & $3.40 * *$ & 2.06760 \\
\hline
\end{tabular}

*;** berturut-turut berbeda nyata pada taraf $\alpha=5 \%$ dan $\alpha=1 \%$; KK: Koefisien keragaman

\section{Produktivitas}

Produktivitas galur padi yang diujikan berkisar antara 5-8 ton ha ${ }^{-1}$. Berdasarkan hasil uji lanjut Duncan diperoleh dua galur memiliki produktivitas yang nyata lebih tinggi dibandingkan varietas pembanding yaitu galur IPB159-F-1 (8.1 ton ha $\left.{ }^{-1}\right)$ dan IPB159-F-13 (7.9 ton $\mathrm{ha}^{-1}$ ) (Tabel 3). Kedua galur tersebut juga memiliki penampilan baik yaitu yang sesuai dengan karakter seleksi galur sehingga menjadi galur seleksi untuk diuji lanjut. 
Galur IPB159-F-1 memiliki karakter seleksi yang baik meliputi jumlah anakan produktif yang baik, panjang malai $30.5 \mathrm{~cm}$, jumlah gabah isi 190 gabah per malai, panjang daun bendera dan persentase gabah hampa yang sesuai dengan karakter seleksi.

Tabel 3. Rekapitulasi nilai tengah berbagai karakter pengamatan

\begin{tabular}{|c|c|c|c|c|c|c|c|c|c|c|}
\hline No & Galur & $\begin{array}{l}\text { Tinggi } \\
(\mathrm{cm})\end{array}$ & $\begin{array}{l}\text { UB } \\
\text { (HSS) }\end{array}$ & $\begin{array}{l}\text { UP } \\
\text { (HSS) }\end{array}$ & $\begin{array}{l}\text { PM } \\
(\mathrm{cm})\end{array}$ & $\begin{array}{l}\text { BSB } \\
(\mathrm{g})\end{array}$ & GT & GI & $\begin{array}{l}\% \\
\mathrm{GH}\end{array}$ & $\begin{array}{l}\mathrm{P} \\
(\text { ton ha-1) }\end{array}$ \\
\hline 1 & IPB158-F-1 & $119^{\text {abcd }}$ & 79 & $123^{\text {bcd }}$ & 20.6 & 24 & $207^{\text {bcd }}$ & $157^{\text {ad }}$ & $22^{\text {abd }}$ & 7.6 \\
\hline 2 & IPB158-F-2 & $124^{\mathrm{abcd}}$ & $84^{\mathrm{b}}$ & 119 & $28.5^{\mathrm{bd}}$ & 27 & $201^{\mathrm{cd}}$ & $184^{\mathrm{cd}}$ & 8.6 & 7.5 \\
\hline 3 & IPB158-F-3 & 103 & $81^{\mathrm{b}}$ & 119 & $28.4^{\text {bd }}$ & 28 & $214^{\text {bcd }}$ & $196^{\text {abd }}$ & $12^{\mathrm{d}}$ & 6.5 \\
\hline 4 & IPB159-F-1 & $119^{\mathrm{abcd}}$ & $89^{\text {bcd }}$ & $121^{\mathrm{bc}}$ & $30.5^{\text {bd }}$ & 28 & $248^{\mathrm{bcd}}$ & $190^{\text {abd }}$ & $24^{\mathrm{abd}}$ & $8.1^{\mathrm{ab}}$ \\
\hline 5 & IPB159-F-2 & $118^{\mathrm{abcd}}$ & 91 & $123^{\text {bcd }}$ & $29.5^{\text {bd }}$ & 25 & $298^{\mathrm{abcd}}$ & $251^{\mathrm{abcd}}$ & $16^{\mathrm{d}}$ & 6.9 \\
\hline 6 & IPB159-F-3 & $113^{\mathrm{abd}}$ & $88^{\mathrm{bcd}}$ & $122^{\text {bcd }}$ & $29.4^{\text {bd }}$ & 27 & $261^{\mathrm{abcd}}$ & $221^{\mathrm{abcd}}$ & $19^{\mathrm{d}}$ & 7.3 \\
\hline 7 & IPB159-F-4 & $115^{\text {abd }}$ & 78 & 118 & $30.2^{\text {bd }}$ & 26 & $278^{\text {abcd }}$ & $208^{\mathrm{abcd}}$ & $24^{\mathrm{abd}}$ & 6.0 \\
\hline 8 & IPB159-F-5 & 102 & 79 & $120^{c}$ & $26.8^{\text {bd }}$ & 24 & $205^{\mathrm{cd}}$ & $182^{\mathrm{bcd}}$ & $10^{\mathrm{d}}$ & 6.5 \\
\hline 9 & IPB159-F-6 & $109^{\mathrm{bd}}$ & $84^{\mathrm{ab}}$ & $121^{\mathrm{bc}}$ & $29.3^{\mathrm{bd}}$ & $28^{\mathrm{abcd}}$ & $249^{\mathrm{bcd}}$ & $195^{\mathrm{abcd}}$ & $17^{\mathrm{d}}$ & 7.0 \\
\hline 10 & IPB159-F-7 & $107^{\mathrm{bd}}$ & $81^{\mathrm{b}}$ & $120^{c}$ & $30.8^{\text {bd }}$ & 25 & $216^{\mathrm{bcd}}$ & $195^{\mathrm{abd}}$ & $14^{\mathrm{d}}$ & 6.9 \\
\hline 11 & IPB159-F-8 & $111^{\mathrm{bd}}$ & 79 & 119 & $29.3^{\text {bd }}$ & $30^{\mathrm{abcd}}$ & $255^{\mathrm{abcd}}$ & $213^{\mathrm{abcd}}$ & $16^{\mathrm{d}}$ & 5.9 \\
\hline 12 & IPB159-F-9 & $107^{\mathrm{bd}}$ & $80^{\mathrm{b}}$ & 113 & $27.0^{\mathrm{bd}}$ & 26 & $256^{\mathrm{abcd}}$ & $191^{\mathrm{abd}}$ & $16^{\mathrm{d}}$ & 5.1 \\
\hline 13 & IPB159-F-10 & $117^{\mathrm{abd}}$ & $81^{\mathrm{b}}$ & 117 & $30.4^{\text {bd }}$ & 26 & $278^{\mathrm{abcd}}$ & $221^{\mathrm{abcd}}$ & $20^{\mathrm{d}}$ & 5.8 \\
\hline 14 & IPB159-F-11 & $110^{\text {bd }}$ & 79 & 117 & $29.4^{\text {bd }}$ & 28 & $251^{\mathrm{bcd}}$ & $208^{\mathrm{abcd}}$ & $12^{\mathrm{d}}$ & 5.7 \\
\hline 15 & IPB159-F-12 & $113^{\mathrm{abd}}$ & $83^{\mathrm{b}}$ & 117 & $31.3^{\text {bd }}$ & $29^{\mathrm{abcd}}$ & $266^{\mathrm{abcd}}$ & $203^{\mathrm{abcd}}$ & $14^{\mathrm{d}}$ & 7.1 \\
\hline 16 & IPB159-F-13 & $126^{\mathrm{abcd}}$ & $88^{\text {bcd }}$ & 119 & $32.3^{\mathrm{c}}$ & 27 & $313^{\mathrm{abcd}}$ & $236^{\mathrm{abcd}}$ & $24^{\mathrm{abd}}$ & $7.9^{\mathrm{ab}}$ \\
\hline 17 & IPB160-F-1 & $106^{\text {bd }}$ & $89^{\text {bcd }}$ & 117 & $28.0^{\text {bd }}$ & 28 & $202^{\text {cd }}$ & $180^{\mathrm{abd}}$ & $10^{\mathrm{d}}$ & 7.8 \\
\hline 18 & IPB160-F-2 & 95 & $90^{\mathrm{bcd}}$ & 117 & $27.0^{\mathrm{bd}}$ & $31^{\mathrm{abcd}}$ & $214^{\mathrm{bcd}}$ & $185^{\mathrm{abd}}$ & $13^{\mathrm{d}}$ & 5.8 \\
\hline 19 & IPB163-F-1 & $110^{\mathrm{bd}}$ & $91^{\text {bcd }}$ & $121^{\mathrm{bc}}$ & $30.0^{\text {bd }}$ & $29^{\mathrm{abcd}}$ & $238^{\text {bcd }}$ & $181^{\text {bcd }}$ & $21^{\mathrm{d}}$ & 7.2 \\
\hline 20 & IPB163-F-2 & 96 & $92^{\mathrm{bcd}}$ & 116 & $27.5^{\mathrm{bd}}$ & 28 & $159^{d}$ & $144^{\mathrm{ad}}$ & 8.9 & 7.0 \\
\hline 21 & IPB163-F-3 & $109^{\mathrm{bd}}$ & $93^{\mathrm{bcd}}$ & 118 & $28.2^{\text {bd }}$ & 26 & $221^{\text {bcd }}$ & $180^{\mathrm{abd}}$ & $16^{\mathrm{d}}$ & 7.3 \\
\hline 22 & IPB165-F-1 & $109^{\mathrm{bd}}$ & $94^{\text {bcd }}$ & $120^{\mathrm{c}}$ & $30.3^{\text {bd }}$ & 28 & $220^{\mathrm{bcd}}$ & $194^{\mathrm{abd}}$ & $14 d$ & 6.8 \\
\hline 23 & IPB165-F-2 & $106^{\mathrm{bd}}$ & $95^{\mathrm{bcd}}$ & $121^{\mathrm{bc}}$ & $31.1^{\mathrm{bd}}$ & 25 & $263^{\mathrm{abcd}}$ & $192^{\mathrm{abd}}$ & $17^{\mathrm{d}}$ & 7.3 \\
\hline 24 & IPB 165-F-3 & $107^{\mathrm{bd}}$ & $96^{\text {bcd }}$ & 119 & $29.8^{\text {bd }}$ & 25 & $245^{\mathrm{bcd}}$ & $201^{\mathrm{abcd}}$ & $25^{\mathrm{abd}}$ & 6.8 \\
\hline 25 & IPB167-F-1 & $107^{\mathrm{bd}}$ & $97^{\mathrm{bcd}}$ & 116 & $28.0^{\text {bd }}$ & $29^{\mathrm{abcd}}$ & $181^{\mathrm{cd}}$ & $138^{\mathrm{ad}}$ & $25^{\mathrm{abd}}$ & 6.2 \\
\hline 26 & IPB167-F-2 & $106^{\mathrm{bd}}$ & $98^{\mathrm{bcd}}$ & 116 & 26.0 & $29^{\mathrm{abcd}}$ & $146^{\mathrm{d}}$ & $114^{\mathrm{d}}$ & $21^{\mathrm{d}}$ & 7.2 \\
\hline 27 & IPB167-F-3 & $110^{\text {bd }}$ & $99^{\mathrm{bcd}}$ & 118 & $28.3^{\text {bd }}$ & 28 & $206^{\mathrm{cd}}$ & $178^{\mathrm{abd}}$ & $13^{\mathrm{d}}$ & 6.9 \\
\hline 28 & IPB168-F-1 & $114^{\mathrm{abd}}$ & $100^{\text {bcd }}$ & 118 & $30.6^{\text {bd }}$ & 28 & $210^{\mathrm{bcd}}$ & $167^{\mathrm{ad}}$ & $21^{\mathrm{d}}$ & 5.0 \\
\hline 29 & IPB168-F-2 & $110^{\text {bd }}$ & $101^{\text {bcd }}$ & 115 & $30.6^{\text {bd }}$ & 25 & $292^{\mathrm{abcd}}$ & $161^{\mathrm{ad}}$ & $21^{\mathrm{d}}$ & 5.8 \\
\hline 30 & IPB168-F-3 & $105^{\mathrm{d}}$ & $102^{\text {bcd }}$ & 117 & $26.8^{\mathrm{bd}}$ & 27 & $143^{\mathrm{d}}$ & $120^{\mathrm{d}}$ & $15^{\mathrm{d}}$ & 6.7 \\
\hline 31 & Ciherang & 111 & 103 & 127 & 27 & 27 & 249 & 115 & 20 & 7.3 \\
\hline 32 & INPARI 13 & 104 & 104 & 120 & 26 & 27 & 201 & 158 & 20 & 7.2 \\
\hline 33 & IPB4S & 117 & 105 & 119 & 29 & 28 & 249 & 194 & 21 & 7.6 \\
\hline 34 & IR64 & 102 & 106 & 121 & 25 & 27 & 106 & 88 & 9 & 7.8 \\
\hline
\end{tabular}

Keterangan : Angka yang diikuti huruf a,b, c, dan d berturut-turut nyata lebih tinggi dari varietas pembanding Ciherang, Inpari 13, IPB 4S dan IR64; UB: Umur Berbunga; UP: Umur Panen; PM: Panjang Malai; BSB: Bobot 1000 Butir; GT: Gabah Total; GI: Gabah Isi; GH: Gabah Hampa; P: Produktivitas

Berdasarkan hasil amatan galur IPB159-F-

13 memiliki panjang malai $32.3 \mathrm{~cm}$ dan merupakan panjang malai terpanjang dibandingkan galur lainnya serta keempat varietas 
pembanding (Tabel 3). Menurut Yang et al. (2007), panjang malai berkolerasi positif terhadap tinggi tanaman, hal ini sesuai dengan hasil uji lanjut yang menunjukkan galur IPB159-F-13 selain memiliki panjang malai terpanjang juga memiliki tinggi tanaman tertinggi yaitu mencapai $126 \mathrm{~cm}$. Seleksi terhadap panjang daun bendera dilakukan untuk daun bendera dengan panjang lebih dari $30 \mathrm{~cm}$. Galur IPB159-F-13 juga memiliki daun bendera terpanjang yaitu $48.17 \mathrm{~cm}$ yang lebih panjang dari empat varietas pembanding. Bobot 1000 butir galur IPB159-F-13 yaitu $27 \mathrm{~g}$ yang tergolong tinggi. Selain itu, galur IPB159-F-13 juga memiliki umur panen yang genjah yaitu 119 HSS. Berdasarkan karakterkarakter unggul yang dimilkinya, maka hasil dari galur IPB159-F-13 tinggi dapat dilakukan uji lanjut.

Berdasarkan pengujian daya hasil, diperoleh galur lain yang memiliki potensi hasil yang tinggi. Galur-galur tersebut memiliki hasil yang setara dengan hasil varietas pembanding. Galur IPB160-F-1 (7.8 ton ha ${ }^{-1}$ ) dan IPB158-F-1 (7.6 ton $\mathrm{ha}^{-1}$ ) dan memiliki produktivitas setara dengan IPB 4S (7.6 ton ha $\left.{ }^{-1}\right)$ dan IR 64 (7.8 ton $\left.\mathrm{ha}^{-1}\right)$. Galur padi IPB158-F-2 (7.5 ton ha $\left.\mathrm{ha}^{-1}\right)$, IPB159-F-3 (7.3 ton ha-1), IPB159-F-6 (7 ton ha$\left.{ }^{1}\right)$, IPB159-F-12 (7.1 ton ha $\left.{ }^{-1}\right)$, IPB165-F-2 (7.3 ton ha $\left.{ }^{-1}\right)$, dan IPB167-F-2 (7.2 ton ha-1) memiliki hasil yang setara dengan varietas Ciherang (7.3 ton $\left.\mathrm{ha}^{-1}\right)$ dan Inpari 13 (7.2 ton ha- $\mathrm{ha}^{-1}$.

\section{Karakter Agronomi Vegetatif dan Generatif Padi}

\section{Tinggi Tanaman}

Tinggi tanaman dari seluruh galur yang diuji berkisar 95-126 cm. Susanto et al. menyatakan bahwa padi tipe baru umumnya memiliki tinggi $80-110 \mathrm{~cm}$ atau $\pm 90 \mathrm{~cm}$. Galur IPB159-F-13 memiliki tinggi tanaman tertinggi yaitu $126 \mathrm{~cm}$ dan galur IPB160-F-2 memiliki tinggi tanaman terpendek $95 \mathrm{~cm}$. Berdasarkan penelitian yang dilakukan oleh Abdullah et al. (2008) tanaman yang memiliki tinggi 90-110 relatif tahan terhdap kerebahan. Peng dan Senadhira (1998) menyebutkan bahwa tanaman yang terlalu tinggi berpotensi mengalami kerebahan yang mengakibatkan menurunnya hasil panen, meningkatkan respirasi, menurunkan translokasi nutrisi serta retan terhadap serangan hama dan penyakit.Tinggi tanaman varietas pembanding Ciherang, Inpari 13, IPB 4S, dan IR 64 berturut-turut yaitu $111 \mathrm{~cm}, 104 \mathrm{~cm}, 117 \mathrm{~cm}$ dan $102 \mathrm{~cm}$.

\section{Daun Bendera}

Daun bendera berpengaruh besar terhadap hasil panen padi, karena merupakan pemasok fotosintat yang berhubungan langsung dengan malai padi (Jennings et al., 1979). Seleksi terhadap daun bendera dilakukan dengan panjang lebih dari $30 \mathrm{~cm}$ atau melebihi panjang malainya, karen hal tersebut dapat meningkatkan potensi hasil (Saniyati, 2012).

Hasil pengamatan menunjukkan bahwa daun bendera yang diuji berada pada kisaran 25 $48 \mathrm{~cm}$. Galur-galur dengan panjang daun bendera $\geq 30 \mathrm{~cm}$ dan tegak berpotensi untuk seleksi. Galur IPB159-F-13 memiliki panjang daun bendera terpanjang $(48.17 \mathrm{~cm})$ yang lebih panjang dari keempat varietas pembanding. Berdasarkan hasil pengamatan, terdapat 29 galur yang memiliki panjang daun bendera $\geq 30 \mathrm{~cm}$.

\section{Anakan Produktif}

Jumlah anakan produktif menjadi karakter generatif penting dalam seleksi galur. Saniyati (2012) menyatakan bahwa jumlah anakan produktif sangat menentukan jumlah malai, jumlah gabah total per malai dan jumlah gabah isi yang merupakan faktor penting dalam menentukan hasil panen. Kush (1996) menyebutkan bahwa menurunkan jumlah anakan tidak produktif merupakan salah satu cara untuk meningkatkan potensi hasil karena dapat meningkatkan aliran nutrisi pasa pembentukan malai. Jumlah anakan produktif pada galur-galur yang diuji berkisar antara 13-25 anakan per tanaman. Abdullah et al. (2008) menyatakan bahwa padi tipe baru memiliki jumlah anakan sedang (9-12) dan semuanya produktif. Galur yang memiliki jumlah anakan produktif yang tinggi yaitu galur IPB163-F-3 dan IPB158-F-2 yang memiliki jumlah anakan sebanyak 25 anakan produktif per tanaman dan lebih tinggi dibandingkan dengan varietas pembanding. Jumlah anakan produktif rata-rata varietas pembanding Ciherang Inpari 13, IPB 4S dan IR 64 masing-masing adalah $22,21,14$, dan 21 anakan produktif.

Hasil pengamatan menunjukkan sebanyak2 galur memiliki anakan produktif berkisar antara 13-14 anakan, 11 galur mempunyai anakan produktif berkisar antara 15-17 anakan, 14 galur memiliki anakan produktif berkisar antara 18-20 anakan, dan 3 galur memiliki anakan produktif lebih dari 20 anakan (Gambar 1). 


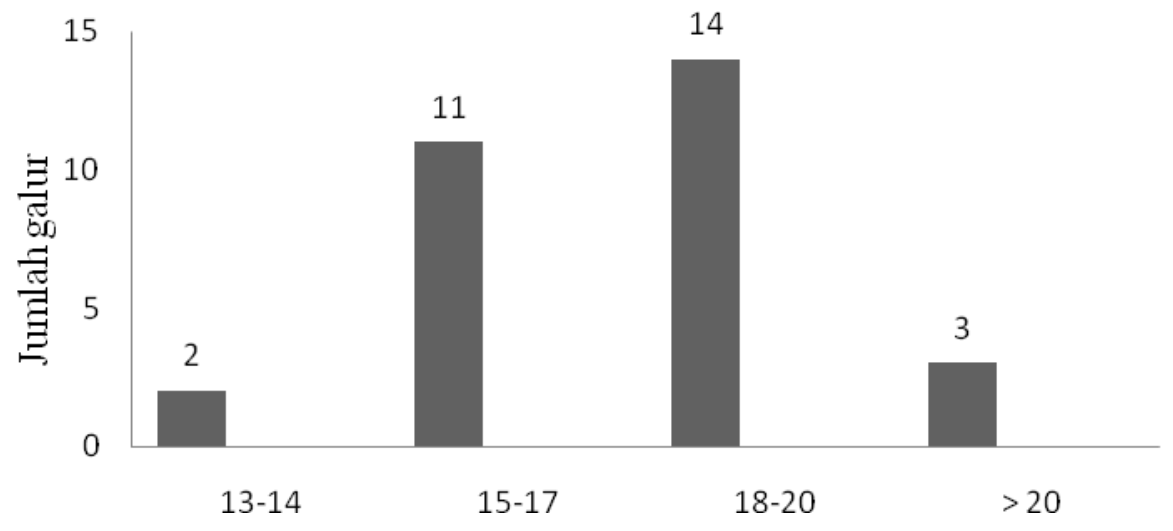

Gambar 1. Sebaran jumlah galur padi yang diuji berdasarkan jumlah anakan produktif

\section{Panjang Malai}

Panjang malai $(\mathrm{cm})$ yang diukur pada penelitian berkisar antara 20-32 $\mathrm{cm}$ (Tabel 4). Hasil uji lanjut Duncan menunjukkan galur IPB159-F-13 memiliki panjang malai terpanjang yaitu $32.3 \mathrm{~cm}$ dan galur IPB158-F-1 memiliki panjang malai terpendek yaitu $20.6 \mathrm{~cm}$. menurut Yang et al. (2007), panjang malai berkorelasi positif terhadap tinggi tanaman, tetapi tanaman yang terlalu tinggi akan rentan terhadap kerebahan yang akan menurunkan potensi hasil panen.

Panjang malai dikelompokkan menjadi tiga kelas yaitu (a) malai pendek $<20 \mathrm{~cm}$, malai sedang 20-30 cm, dan (c) malai panjang $>30 \mathrm{~cm}$. Berdasarkan hasil pengamatan diperoleh 1 galur memiliki panjang malai yang tergolong pendek, 25 galur memiliki panjang malai sedang (20-30 $\mathrm{cm}$ ), dan 4 galur memiliki panjang malai yang panjang yaitu $>30 \mathrm{~cm}$.

Tanaman padi yang memiliki malai yang panjang dapat mengurangi hasil, karena berpotensi berkembang tidak baik disebabkan gabah pada pangkal malai terbungkus daun bendera sehingga tidak keluar. Kondisi tersebut juga dapat menimbulkan serangan hama dan penyakit pada gabah. Panjang malai yang tergolong panjang sebaiknya memiliki persen gabah hampa yang rendah dan gabah isi yang tinggi agar berpengaruh baik terhadap peningkatan hasil. Panjang malai untuk varietas pembanding pada hasil penelitian ini yaitu Ciherang $27 \mathrm{~cm}$, Inpari $1326 \mathrm{~cm}$, IPB 4S $29 \mathrm{~cm}$, dan IR $6425 \mathrm{~cm}$.

\section{Umur Berbunga dan Umur Panen}

Umur berbunga (HSS) diukur saat $80 \%$ masing-masing galur berbunga. Umur berbunga galur padi yang diuji berkisar antara 78-93 HSS. Galur IPB159-F-4, IPB159-F-5, IPB167-F-1, IPB167-F-2, dan IPB167-F-3 memiliki umur berbunga paling cepat 78 HSS dibandingkan galur-galur lain serta varietas pembanding IPB $4 \mathrm{~S}$ (85 HSS), Inpari 13 (79 HSS), dan IPB 4S (88 HSS) dan Ciherang (93 HSS). Varietas pembanding Ciherang memiliki umur berbunga paling lama yaitu 93 HSS. Galur yang memiliki umur berbunga yang lama dibandingkan varietas Ciherang yaitu IPB159-F-1, IPB159-F-2, dan IPB160-F-1.

Padi dengan umur genjah adalah karakter yang disukai petani. Umur panen (HSS) dihitung saat $90 \%$ bulir pada setiap galur telah masak. Umur panen pada galur-galur yang diujikan berkisar antara 133-127 HHS. Galur padi penelitian yang memiliki umur paling genjah yaitu galur padi IPB159-F-9 (113 HSS) dan yang paling lama adalah galur padi IPB159-F-2 (125 HSS). Varietas pembanding Ciherang memiliki umur panen paling lama (127 HSS).

\section{Bobot 1000 Butir}

Cempaka (2007) Menyatakan bahwa bobot seribu butir menjadi pertimbangan dalam seleksi padi tipe baru, semakin berat bobot 1000 butir maka semakin tinggi produksinya. Berdasarkan hasil pengamatan, sebesar $93 \%$ dari galur-galur yang diuji memiliki bobot 1000 butir $\geq 25$ gram. Galur IPB160-F-2 memiliki bobot 1000 butir tertinggi $(31.047 \mathrm{~g})$ dan galur memiliki bobot 1000 butir terendah yaitu IPB158-F-1 (24 g). Hasil pengamatan menunjukkan bahwa galur IPB159-F-7, IPB159-F-12, IPB160-F-2, IPB163F-1, IPB167-F-1, dan IPB167-F-2 memiliki bobot 1000 butir yang lebih tinggi dari varietas 
pembanding IPB 4S. Bobot 1000 butir masingmasing varietas pembanding yaitu Ciherang $27 \mathrm{~g}$, Inpari 1327 g, IPB 4S 28 g danIR $6427 \mathrm{~g}$.

\section{Gabah}

Gabah isi merupakan karakter generatif yang penting untuk seleksi. Gabah isi dihitung dengan pengurangan gabah total dengan gabah hampa. Jennings et al. (1979) menyatakan bahwa gabah isi merupakan karakter yang sangat mempengaruhi potensi hasil. Jumlah gabah total yang banyak, dengan persentase gabah isi yang tinggi (minim gabah hampa) merupakan karakter seleksi yang diinginkan. Berdasarkan hasil pengamatan, jumlah gabah total berkisar antara 106-312 gabah per malai. Galur padi IPB158-F-3 memiliki jumlah gabah isi tertinggi yaitu 251 butir/malai, sedangkan galur IPB167-F-2 memiliki jumlah gabah isi terendah yaitu sebanyak 114 butir/malai. Galur padi IPB163-F-2 memiliki jumlah gabah hampa terendah (14 butir/malai) dan galur IPB159-F-13 memiliki jumlah gabah hampa tertinggi (75 butir/malai). Zheng-jing (2010) menyatakan bahwa tingginya jumlah gabah total berpotensi meningkatkan jumlah gabah hampa. Galur IPB159-F-13 memiliki jumlah gabah total tertinggi yaitu 313 butir/malai dengan jumlah gabah hampa yang tinggi yaitu 75 butir/malai (persentase gabah hampa 24\%).

Persentase gabah hampa merupakan pembagian jumlah gabah hampa dengan jumlah gabah total dikalikan $100 \%$. Hasil pengamatan menunjukkan persentase gabah hampa terendah dimiliki oleh galur IPB158-F-2 yaitu sebesar 8.6\% (gabah total 201 butir/malai) dan persentase gabah hampa tertinggi dimiliki oleh galur IPB167-F-3 yaitu sebesar 25\% (gabah total 206 butir/malai). Persentase gabah hampa varietas pembanding yaitu Ciherang 20\%, Inpari $1320 \%$ dan IPB 4 S $28 \%$ dan IR $649 \%$.

\section{KESIMPULAN}

Galur IPB159-F-1 dan IPB159-F-13 memiliki hasil yang lebih tinggi dari varietas pembanding. Galur IPB158-F-2, IPB159-F-3, IPB159-F-6, IPB159-F-12, IPB165-F-2, IPB167F-2, IPB158-F-1, IPB159-F-2, IPB160-F-1 memiliki hasil yang setara dengan varietas pembanding galur-galur tersebut juga memiliki karakter yang sesuai karakter seleksi, sehingga berpotensi untuk pengujian lanjutan untuk dikembangkan menjadi varietas unggulan.

\section{DAFTAR PUSTAKA}

Abdullah B., S. Tjokrowidjojo, danSularjo. 2008. Status, Perkembangan, dan Prospek Pembentukan Padi Tipe Baru di Indonesia. Prosiding Simposium V Tanaman Pangan; Inovasi Teknologi Tanaman Pangan, Buku 2: Penelitian dan Pengembangan Padi. Bogor (ID): Pusat Penelitian dan Pengembangan Tanaman Pangan.

Alnopri. 2004. Variabilitas genetik dan heritabilitas sifat-sifat pertumbuhan bibit tujuh genotipe kopi robusta-arabika. JIPI. 6(2): 91-96.

Bahar H dan Zen S. 1993. Parameter genetik pertumbuhan tanaman, hasil dan komponen hasil jagung. Zuriat 4 (1): 4-7

[BPS] Badan Pusat Statistik (ID). 2011. Produksi padi, jagung, dan kedelai [Internet]. [diunduh 2012 Februari 4]. Tersedia pada http:www.bps.go.id.

[BPS] Badan Pusat Statistik (ID). 2012. Produksi padi, jagung, dan kedelai [Internet]. [diunduh 2012 Oktober 3]. Tersedia pada http:www.bps.go.id.

[BPS] Badan Pusat Statistik (ID). 2012. Laju pertumbuhan penduduk Indonesia menurut provinsi [Internet]. [diunduh 2012 Februari 2]. Tersedia pada http://www.bps.go.id.

[BBP Padi] Balai Besar Penelitian Tanaman Padi. 2009. Deskripsi Varietas Padi. Balai Besar Penelitian Tanaman Padi. Subang (ID): BBP Padi Pr. "105 hlm".

Cempaka IG. 2007. Uji Daya Hasil Lanjutan Galur Harapan Padi Sawah Tipe Baru (Oryza sativa L.) di Kabupaten Cilacap, Jawa Tengah. Bogor (ID): Institut Pertanian Bogor

Gomez KA, Gomez AA. 1995. Prosedur Statistika untuk Penelitian Pertanian. Sjamsudin E, Baharsjah JS, penerjemah. Jakarta (ID): UI Pr. Terjemahan dari: Statistical Prosedures for Agricultural Research. "698 hlm".

Jennings PR, WR Coffman, HE Kauffman. 1979. Rice Improvement. International Rice Research Institute. Los Banos (PH). “186 hlm". 
Kush GS. 1996. Prospeect and aproach to increasing the genetic yield potential of rice. In RE Venson, RW Herdit, M Hossain (Eds) Riece Research in Asia: Progress and Priorities. Philippines (PH): IRRI.

Las I, B. Abdullah, dan A.A Darajat. 2003. Padi tipe baru dan padi hibrida mendukung ketahanan pangan. Tabloid Sinar Tani [Internet]. [diunduh 2012 Februari 10]. Tersedia pada http://www.litbang.deptan.go.id/artikel/one/ 23/pdf.

Las I, IN Widiarta, B. Suprihatno.2004. Perkembangan Varietas dalam Perpadian Nasional. "hlm 1-25".

Lestari AP, H. Aswidinnoor, Suwarno. 2007. Uji daya hasil pendahuluan dan mutu beras 21 padi hibrida harapan. Bul. Agron. 35(1)1-7.

Makarim AK, E. Suhartatik. 2006. Budidaya padi dengan masukan in situ menuju perpadian masa depan. Iptek Tanaman Pangan 1:1929.

Makarim AK, E. Suhartatik. 2009. Morfologi dan Fisiologi Tanaman Padi. In Suyamto, I Nyoman Widiarta, Satoto (Eds) Padi: Inovasi Teknologi dan Ketahanan Pangan. Buku 1. Jakarta (ID): LIPI

Martono B. 2004. Keragaman genetik dan heritabilitas karakter ubi bengkuang (Pachyrhizus erosus (L.) Urban). Sukabumi (ID) : Balai Penelitian Tanaman Rempah dan Aneka Tanaman Industri.

Poehlman JM and DA Sleeper. 1995. Breeding field crops. Lowa (US). Lowa State Univ Pr.

Poespodarsono S., 1988. Dasar-dasar Ilmu Pemuliaan Tanaman IPB. Bogor (ID). "196 hlm".

Pramono J., Basuki S., dan Widarto. 2005. Upaya peningkatan produktivitas padi sawah melalui pendekatan pengelolaan tanaman dan sumberdaya terpadu. Agrosains 7(1):16.

Syukur M, S. Sujiprihati dan R Yunianti. 2012. Pemuliaan Tanaman. Jakarta (ID) : Penebar Swadaya. "348 hlm".

Saniyati A. 2012. Uji daya hasil pendahuluan 100 galur zuriat F5 padi tipe baru hasil dari kombinasi 3 persilanganIPB117-F-5-1-1 x IR64, IPB98-F-5-1-1 x IR64, dan Cimelati x IPB97-F-31-1-1 [skripsi].Bogor (ID): Institut Pertanian Bogor.

Yang W et al. 2007. Graind yield attributes of new plant type and hybrid rice. Crop Science 47: (1393-1400). Zheng-jing XU et al. 2010. Genetical and physiological basis of plant type model of erect and large panicle japonica super rice in China 9(4): 457- 462. 